arranged, dealing with progesterone and the defence mechanism of pregnancy; biological activity of the leucocyte; the mechanism of action of water-soluble vitamins; and curare and curare-like agents; while seven discussion meetings were also arranged. At the three Dunant Coterie dinners the subjects of discussion included the Yeti 'scalp', medical education and research in Africa and Asia, the barrier function of the small intestinal mucous membrane, and some implications of the use of food additives. In the winter a series of film sessions, besides prize-winning medical films from abroad, French films on tropical medicine and an international selection of recent medical films, were shown. The thirteenth Ciba Foundation lecture, delivered by Prof. E. Katchalski, dealt with synthetic macromolecules as protein models. Three Anglo-French bursaries were awarded by the British Selection Committee and two by the French Selection Committee. Besides lists of publications in print or in preparation and accessions to the library, full details of the symposia and colloquia are appended to the report.

\section{Scottish Field Studies Association}

IT is regrettable that the strong student support given to the Scottish Field Studies Association has not been matched by similar financial support. The annual report describes the fine work the Association is doing in Scotland, and makes it clear that no real progress can be made until the Association has a Field Centre of its own and enough money to make tidy administration possible (The First Ten Years. By B. W. Ribbons. Annual Report, 1961. Glasgow: The Scottish Field Studies Association). The modest sum required would not seem to be beyond the resources of industrial and charitable organizations in Scotland. Details of the courses available in 1962 and how help can be given to the Association are obtainable from the Secretary, 179 West Regent Street, Glasgow, C.2.

\section{Sir John Hammond: a Pioneer in Modern Farm Animal Breeding}

The February issue of Animal Production (4, Part $1 ; 1962$ ) is devoted to the jubilee of Sir John Hammond, the pioneer of the modern outlook on the breeding of farm animals in Britain and a world leader in the physiology of fertility. Elizabeth O. Cockburn has contributed a most interesting account of his career and there is a characteristic photograph of him arriving with his bicycle for the dinner in his honour. Steeped in agriculture and of an old-established veterinary family in the eastern counties, he intended to qualify and become a third generation in the profession, but not having done Latin at school the need to study it for the entrance examination led almost fortuitously to a change in programme and he entered the then new Agricultural Department of Cambridge, with results that have so fortunately influenced much of the quality of farm livestock. To-day, Hammond's pupils and collaborators are found in all or most of the countries with strong livestock interests. The achievement in 1958 of the breeding of ten million cattle by artificial insemination under the auspices of the British Milk Marketing Board can be traced to his pioneer activities. No less remarkable is the wide range of physiology explored and developed from Cambridge in the course of researches on the reproductive system, following, of course, on the foundations laid by the late F. H. A. Marshall. A selected bibliography accompanies this biographical note. The Journal of Reproduction and Fertility $(3$, No. $1 ; 1962)$ is concurrently marking Hammond's contribution to the study of reproductive physiology.

\section{Irish Journal of Agricultural Research}

THe first number of the Irish Journal of Agricul. tural Research, issued by An Foras Talúntais (Agricultural Institute), Dublin, which became available in 1961 (1, No. 1; October 1961. Pp. 82. Published twice yearly. Annual subscription, 20s.; 3 dollars. Single number, $10 s . ; 1.50$ dollars), provides a means whereby research workers in all branches of agricultural science including soils, plants and animals, engineering, economics and sociology can publish the results of their researches and will appeal primarily to scientific workers in agriculture. The first number contains papers covering a wide field ranging from soil analysis, cereal root eelworm, tomato culture, management of bogland, supplementary feeding of lambs and marketing of agricultural output.

\section{The British Journal of Social and Clinical Psychology}

The British Journal of Social and Clinical Psychology is to be devoted to social psychology and abnormal and clinical psychology (1, Part 1; February 1962. Pp. 80. Edited by Michael Argyle and Jack Tizard. Published three times per annum. Subscription price per volume, $50 s$.; 8.50 dollars. Separate parts, $20 s$; 3.50 dollars. London and New York: Cambridge University Press). Papers on industrial, gerontological and sociological matters, such as delinquency, are to be included so long as they deal with psychological questions. This seems an excellent programme, and the first issue sets a good example which it is to be hoped will be followed by those to come. There are two papers on schizophrenia, one on personality questionnaires, another on space concepts in the mentally subnormal. Others are on institutionalism in mental hospitals, maternal attitudes to child socialization, and the attitudes of teachers to education. There is also a study of performance of tests of memory and learning in elderly patients. There are to be book reviews, and the books reviewed in this issue are given adequate notices. In the past, journals of this nature have tended to be either entirely clinical or else devoted to pure psychology, so that papers on the application of such things as psychological tests on abnormal patients have been pushed into odd corners. Now, with this new journal, they will be certain of reaching those who are interested in them, and the writers will not feel that they are being published on sufferance by editors who would prefer to devote their space to different matters. Everyone interested in psychology and psychiatry will welcome this journal and hope that it will have a long and successful career.

\section{Association of Applied Biologists}

THe following honorary officers were elected for 1962-63 at the recent annual general meeting: President, Prof. H. G. H. Kearns; Vice-President, Dr. J. S. Kennedy; President-Elect, Prof. A. H. Bunting; Treasurer, Dr. F. Raw; General Secretary, Dr. F. T. Last (Glasshouse Crops Research Institute, Rustington, Littlehampton, Sussex); Programme Secretary, M. J. Way; Editor, R. W. Marsh; Assistant Editor, Dr. I. Thomas. New members of Council elected were: Prof. J. Colhoun, Dr. S. H. Crowdy, J. E. E. Jenkins, R. M. Lister and A. H. Strickland. 